\title{
LESÕES POUCO USUAIS NA HISTOPATOLOGIA EXPERIMENTAL DE ARBOVIRUS AMAZÔNICOS
}

\author{
Leonidas Braga Dias, Francisco Duarte e Domingos de Paola
}

\begin{abstract}
São descritas as alteraçōes histopatologicas observadas em camundongos infectados experimentalmente com os arbovirus MUcambo, EEE $e$ Cocal. O virus $M u c a m b o$ determinou lesōes renais; O EEE demonstrou especial mesenquimotropismo; o virus cocal lesôes de topografia seletiva subependimária.
\end{abstract}

Vários autores têm se preocupado com a descrição das lesões experimentais produzidas por arbovirus, quer do grupo A (1, 9 e 15$)$, como do grupo B $(2$ e 3$)$ e C $(6$, $7,8)$

De um modo geral as lesōes comumente descritas estão limitadas ou ao sistema nervoso central ou ao fígado $(1,3,6,7 \mathrm{e}$ 8 ), e excepcionalmente em outros setores do organismo, como o caso do virus Aurá, determinando lesões no miocárdio (9); focos de necrose têm sido assinalados em gânglios linfáticos e na medula óssea de cobaios e coelhos infectados com virus VEE (15). Hiperemia renal com obliteração do espaço de Bowman foi descrita por Smithburn (12) na infecção experimental pelo virus Semliki; a degeneração muscular, com necrose focal tem sido identificada na patologia dos virus Middelburg e Chikungunya (10 e 16) e Sindbis (13) imitando as lesões determinadas pelos virus do grupo Coxsackie. Da mesma maneira, a necrose da gordura hibernante "brown fat") descrita neste grupo de virus tem sido também referida na infecção experimental de camundongos com virus Getah (14) e Sagiyama (11).

O mesenquimotropismo de alguns virus não tem sido convenientemente enfatizado, em que pese a ocurrência de complexos antígeno-anticorpo-fluoresceína na infecção experimental pelo vírus Junin, Oriboca, e do grupo VSV (4,5 e 8), em células do tecido conjuntivo.

O presente relato tem por objetivo assinalar algumas lesões pouco usuais detectadas no curso da infecção experimental de camundongos por virus Mucambo, EEE e Cocal.

\section{MATERIAL E MÉTODOS}

Foram utilizadas as amostras BeAn 94768 (Mucambo), BeAn 119081 (EEE) e BeAr 39377 (Cocal) ,

A amostra de virus Mucambo foi isolada de urina de um oryzomis goeldii por inoculação da mesma em camundongo recemnascido, estando aquele roedor silvestre com hematúria. Foram inoculados lotes de 6 animais adultos, para cada título

Trabalho do Centro Regional de Patologia da Faculdade de Medicina da Universidude Federal do Pará e do Departamento de Patologia da Faculdade de Medicina da Universidade Federal do Rio de Janeiro. Recebldo para publicacáo em $17,4,1972$. 
(10-: a $10^{-1}$ e via de inoculação cerebral e intraperitoneal utilizando 0.02 e $0.03 \mathrm{ml}$. respectivamente', com suspensāo de virus procedente do liofilizado de cérebro de camundongo recemnascido, em primeira passagem. Os animais, num total de 19 , foram sacrificados em dias sucessivos, a partir do 6 ' dia de inoculação; o sacrifício foi por decapitação, sem anestesia, com imediata retirada das visceras, que foram fixadas ern formol neutro a $10 \%$ e em líquido de Bouin, de preparo recente.

A amostra de virus EEE foi inoculada em lotes de 6 animais recemnascidos e 6 animais adultos, utilizando igualmente as vias cerebral e intraperitoneal, variando as diluiçōes entre $10^{-1}$ a $10^{-"}$. Todos os camundongos foram anestesiados, sacrificados e fixados em formol neutro a $10 \%$. Os animais adultos foram necropsiados e retirados quase todos os órgãos, incuindo a pele e músculos. Os animais recemnascidos foram fixados in toto, após incisāo na cavidade craniana e tóraco-abdominal, para facilitar a penetraçāo do fixador. Os animais foram sacrificados com sintomas paralíticos no $4^{\circ}$ e $7^{\circ}$ dia após inoculação (recemnascidos) e no $10^{\circ}$ dia após inoculação, um único animal adulto.

A amostra de virus Cocal foi isolada de um lote de 119 Gigantolaslaps colhidos do oryzomys sp. capturados com armadilhas na floresta do $\mathrm{Km} .92$ da rodovia BelémBrasília. Nas reações com soros dos grupos de Belém, e protótipos, ele reage somente com seus anti-soros homólogos, tendo sido negativa com 19 imune-soros para tipos exóticos, incluindo os tipos de soro Indiana e New Jersey do grupo da Estomatite vesicular. Entretanto as provas que resultaram de pcrmuta de imune-soro entre os laboratórios de Trinidad e Belém indicam que o BeAr 39377 e $\mathrm{Tr}$ Vl 40233 (isolado em Port of Spain) apresentam relações entre si. Foram examinados 17 camundongos de 4 dias de idade, inoculados por via cerebral, com $0.02 \mathrm{ml}$. de virus do soro de camundongo, 8a passagem, com títulos que variaram de $10^{--3}$ a $10^{--}$utilizados no curso de provas de neutralização. Foram sacrificados os animais não protegidos, que se apresentaram moribundos ou paraliticos. O tempo médio de sobrevivência dos animais inoculados e sem protecão foi de 2 dias $(10-:$ e 10-4). Foram, em realidade, realizadas 3 provas de neutrali- zação (proteçāo), resultando 6 animais da primeira experiência, 6 da segunda e $5 \mathrm{da}$ terceira.

\section{RE'SULTADOS}

Em relação ao virus Mucambo, os resultados histopatológicos nâo dependeram da via de inoculação e nem variaçōes quantitativas foram observadas em função do título do inóculo. Em todos os animais que se apresentaram moribundos foi constatada a presença de quadro encefalítico (figura 1). Além desses achados de agressāo neuronal foram assinaladas aterações hepáticas variáveis figura 2) representadas por graus variáveis de vacuolização dos hepatócitos, necrose focal ocasional, anisocariose pouco pronunciada e discreta proliferação mesenquimal. Chamou-nos atençào o comprometimento renal (figura 3 ). Em 8 animais foram observadas alterações renais do tipo da glomerulite hemorrágica; em 4, do tipo glomerulite proliferativa e em 1, proligeração do epitélio capsular. Em 8 animais foi descrita congestāo glomerular ou intersticial, isolada ou com as demais lesc̄es acima descritas; não foram observados dados dignos de registro em apenas 3 animais

$O$ virus EEE, em camundongos recemnascidos apenas, determinou lesões ao nível do tecido conjuntivo jovem, incluindo pericondrio, periosteo e bainha tendinosa (figura 4). Tais lesóes estavam caracterizadas por focos necróticos, traduzidos por cariorrexe e cariopicnose, assim como imagens de lise celular, a par de moderado edema. Com menor freqüência foi assinalado igual tipo de comprometimento no intersticio miocárdico

o que se assinala de especial em relação ao quadro histopatológico da infecção experimental pelo virus Cocal é, no quadro encefalítico, a presença de lesōes subepenảimárias, de topografia constante, representadas por imagens de cariólise e cariorrexe não só ao nível das células neuronais como também gliais (figuras 5,6 . 7 e 81

\section{COMENTÁRIOS}

De um modo geral, a análise da patologia experimental dos virus Mucambo. EEE e Cocal, demonstra lesões poucc 
usuais quando comparadas com as identificadas com outros arbovirus $(6,7)$. Mesmo o quadro encefalitico, caracteristico dos arbovirus em geral quando inoculados em camundongos recemnascidos, mostra, no caso do vvirus Cocal, uma topografia seletiva sub-ependimária, achado que nāo se confirma com outros arbovirus. O mais importante, entretanto, é a possibilidade de identificaçāo nāo só de lesões ao nível das células de linhagem neuronal, como, muito particularmente, na neurogia.

A análise histopatológica do virus $\mathrm{Mu}$ cambo, isolado originariamente de um roedor silvestre com hematúria, é também um achado singular, unicamente comparável com as lesões produzidas pelo virus Semliki 112,

Talvez de importância apreciável, pelo menos do ponto de vista doutrinário, é a identificacão de lesões ao nível de células do tecido conjuntivo, isto é, em tecido de sustentaçāo, fato só recentemente estabelecido com o emprego de técnicas de imu- nofluorescência $(4,5$ e 8$)$. O certo è que com metodologia mais sofisticada surpreende-se o complexo virus-anticorpofluoresceina em células conjuntivvas, sem entretanto a detecção, pelo menos em nivel de microscopia ótica, de lesóes celulares. No exemplo que apontamos, isto é, o virus EEE, as lesēes foram identificadas facilmente à microscopia ótica.

Farece-nos, no momento atual, da maior importáncia reconhecer a participação do tecido de sustentaçāo na agressão viral, uma vez que numerosas conjecturas etiológicas, ainda meramente especulativas, têm sido apontadas no determinismo de doenças humanas.

\section{AGRADECIMENTOS}

Grande parte da elaboraçāo deste trabalho foi efetuada no Instituto Evandio Chagas (Belém - Pará). À sua direção e corpo de pasquisadores e técnicos, nossos agradecimentos.

\section{SUMMARY}

A description is given of the histopathologisal changes observed in mice infected experinentally with Mucambo, EEE and Cocal arboviruses. Mucambo virus induced renal lesions; EEE virus demonstrated special mesenchymal tropism; Cocal vinu produced changes celectively in subependimal region.

\section{REFERENCIAS BIBLIOGRÁFICAS}

1. BAKER, A. B. - Western equine encephalitis. In Encephalitis. Elsevier, p. $33-37,1961$.

2. BEARCROFT, W. G. C. - The histopathology of the liver of yellow feverinfected Rhesus monkey. J. Path. \& Bact. 74: 295-303, 1957.

3. BRUNO-LOBO, G. e CAUSEY, O. Bussuquara, a new arthropod-borne virus. Proc. Soc. Exp. Biol. Med. 101: 275-279, 1959.

4. BRUNO-LOBO, G.; BRUNO-LOBO, M.; JOHNSON, K. M.; WEBB, P. A. e De PAOLA, D - Pathogenesis of Junin virus infection in the infant hamster. An. Microbiol. 15: 11-33, 1968.
5. BRUNO-LOBO, M.: PERALTA, P. H. : BRUNO-LOBO, G. E De PAOLA, D. Pathogenesis of Vesicular stomatitis virus infection in the infant hamster and mouse. An. Microbiol: 15: 53-68, 1968 .

6. De PAOLA, D. - Contribuição ao estudo da patologia das arborviroses. Tese. Rio de Janeiro. 1964.

7. De PAOLA, D: BRUNO-LOBO, M. e DUARTE, F. - Histopatologia experimental dos arbovirus do grupo $\mathrm{C} e$ Guamá. An. Microbiol. 11: 133-160. 1963 .

8. De PAOLA, D ; BRUNO-LOBO, G BRUNO-LOBO, $M$. - Immunofluores. 
cense in pathogenesis of group A, B and $\mathbf{C}$ arbovirus in the hamster. An. Microbiol. 15: 35-51. 1968.

9. DIAS, L. B. - Miocardite experimental em camundongos produzida por virus Aura. Atas Simp. Biota Amazon. 6: 95-97, 1966

10. KOKERNOT, R. H.; MEILLON, B. de; PATERSON, H. E.; HEYMAN, C, S. e SMTTHBURN, K. C. - Middelburg viruses. A hitherto unknown agent isolated from Aedes mosquitos during an epizootic sheep. South Afr. Med. Sci. 22: 145-153, 1957.

11. SCHERER, W. F.; IZUMI, T.; Mc COWN, J. e HARDY, J. L. - Sagiyama virus. II. Some biologic. physical, chemical and immunologic properties. J. Trop. Med. and Hyg. 11: 269-282, 1962.

12. SMITHBURN, K. C. - Neurotropic viruses in Central Africa. Proc. 4th.
Cong. Trop. Med. \& Malaria, p. 576$583,1948$.

13. TAYLOR, R. M.; HURLBUT, H. S.; WORK, T. H.; KINGSTON, J. R. e FROTHINGHAM, T. E. - Sindbis virus: a newly recognized arthropodtransmited virus. Am. J. Trop. Med. \& Hyg. 4: 844-862, 1955.

14. TAYLOR, R. M. (ed.) - Catalogue of Arthropod-borne viruses of the World. U. S. Gov. Printing Office, 1967.

15. VICTOR, J.; SMITH, D. G. and POLLACK, A. B. - The comparative pathology of Venezuelan encephalomyelitis. J. Infec. Dis. 98: 55-56, 1956.

16. WEINBREN, M. P. - The occurence of Chikungunya virus in Uganda. III. Identification of the agents. Trans. Roy. Soc. Trop. Med. \& Hyg. 52: $259-$ 262,1958 . 


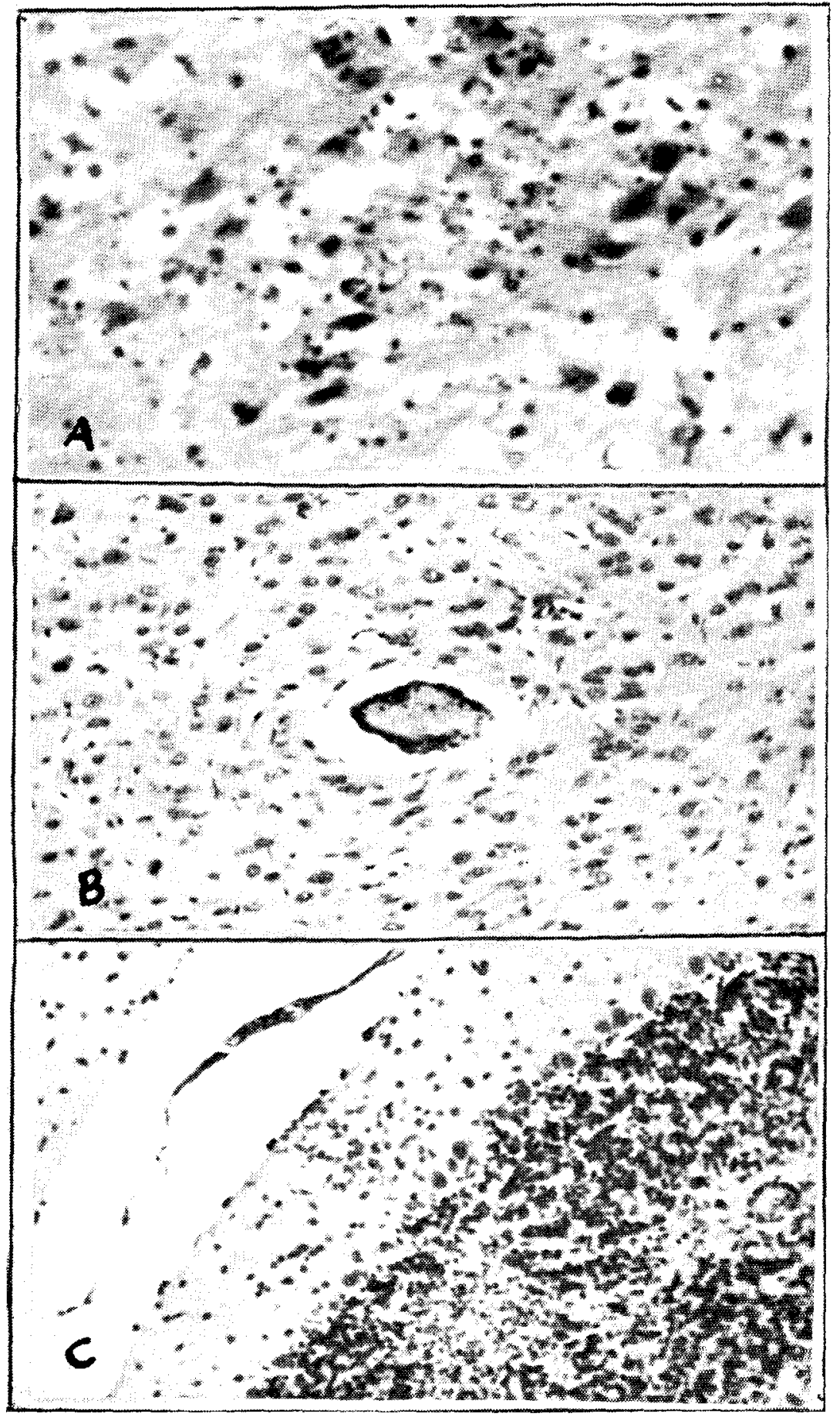

Fig. 1 - MUCAMBO)

Em (A) extensa e severa destruição netronai no nivel da cortex frontal: em (B) infiltrado mononuclear perivascular e proliferacăo glial com figuras de neuronofagia; em $(C)$ cerebelo exibindo destrucaca de cèlulas $240 \mathrm{x}$ e $120 \mathrm{X}$. proliferaça microglial em tufo (glial schrub). H \& $\mathrm{E}$. 


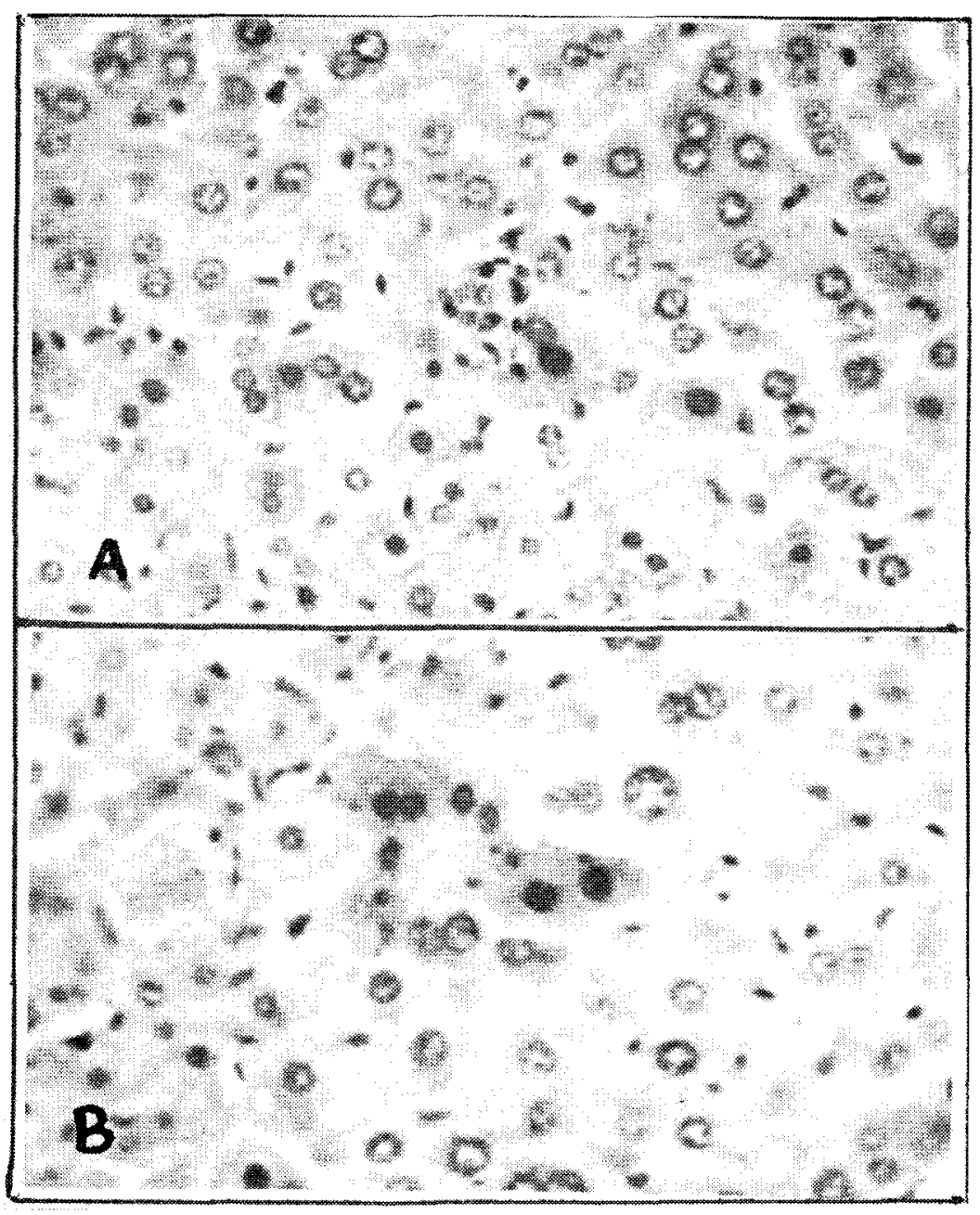

Fig. 2 - I MUCAMBO

Em (A) e (B) lesóes focais de hepatocitos, e proliferacảo de celullas de
Kupfer, H \& E $240 \mathrm{X}$. 


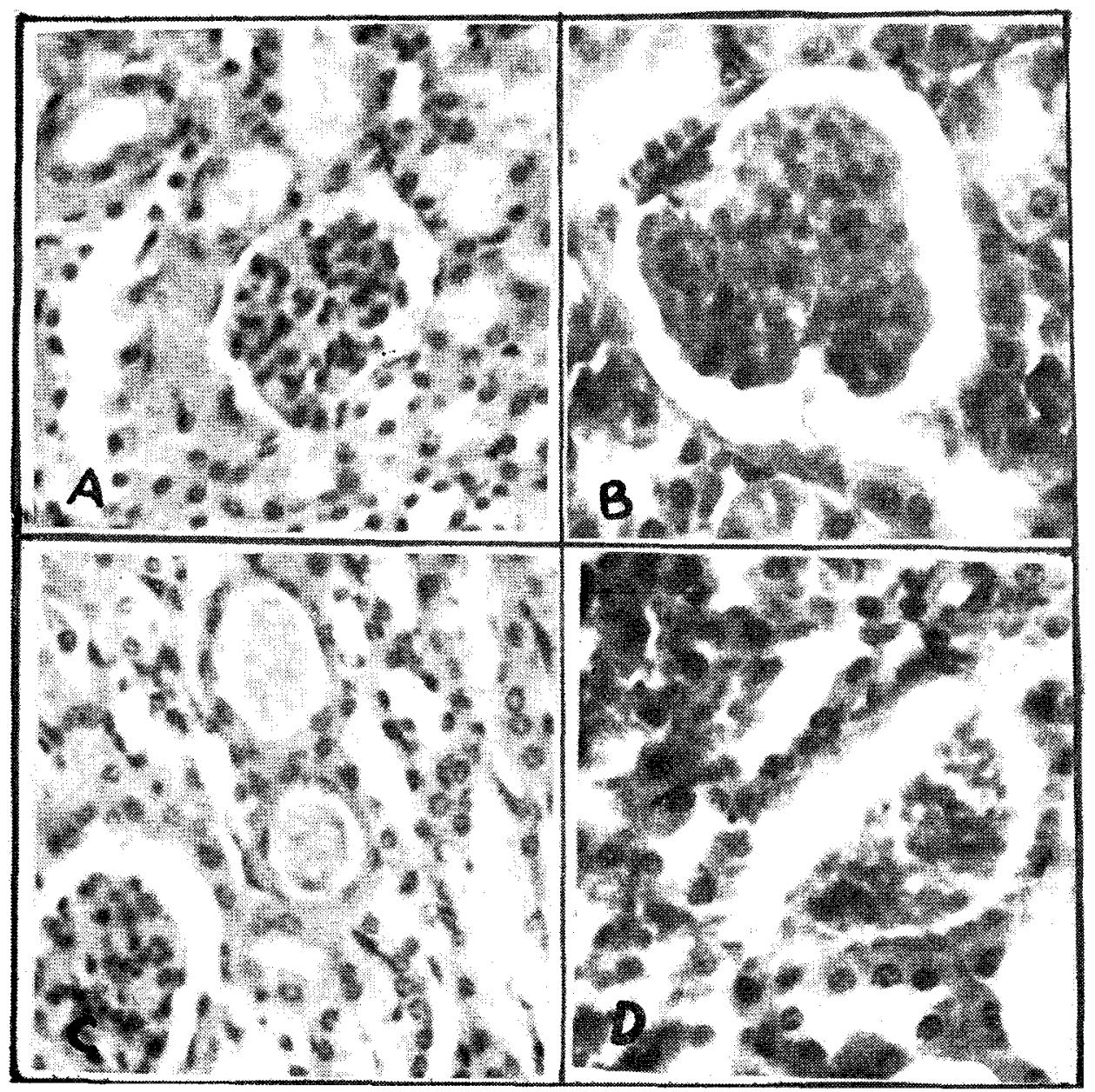

rig. $3-$ MUCAMBO,

Em (A) e (B) plomérulo renal exibindo proliferacāo celular e intensa conmestéo $20 \mathrm{X}$ o $240 \mathrm{X}$. tubulos renais contendo material proteinemen e hematias. $\mathrm{H}$. $d \mathrm{E}$. 


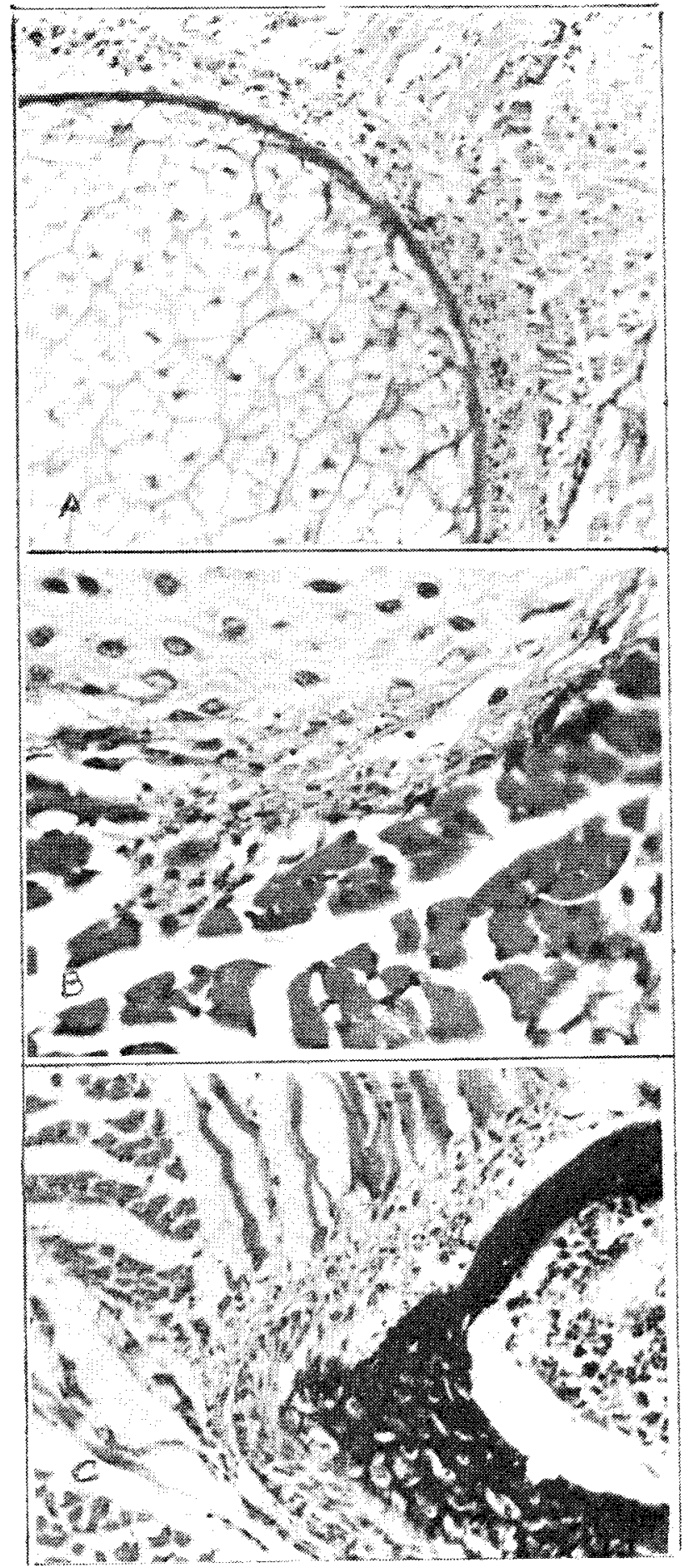

Fig. $4-$, E E E )

Em (A) e (B) areas circunscritas de degeneraçāo e necrose do pertcôndrio costal. H. \& E 120 X e $240 \mathrm{X}$ Em $(C)$ degeneraçāo e necrose do periósteo, exten- 


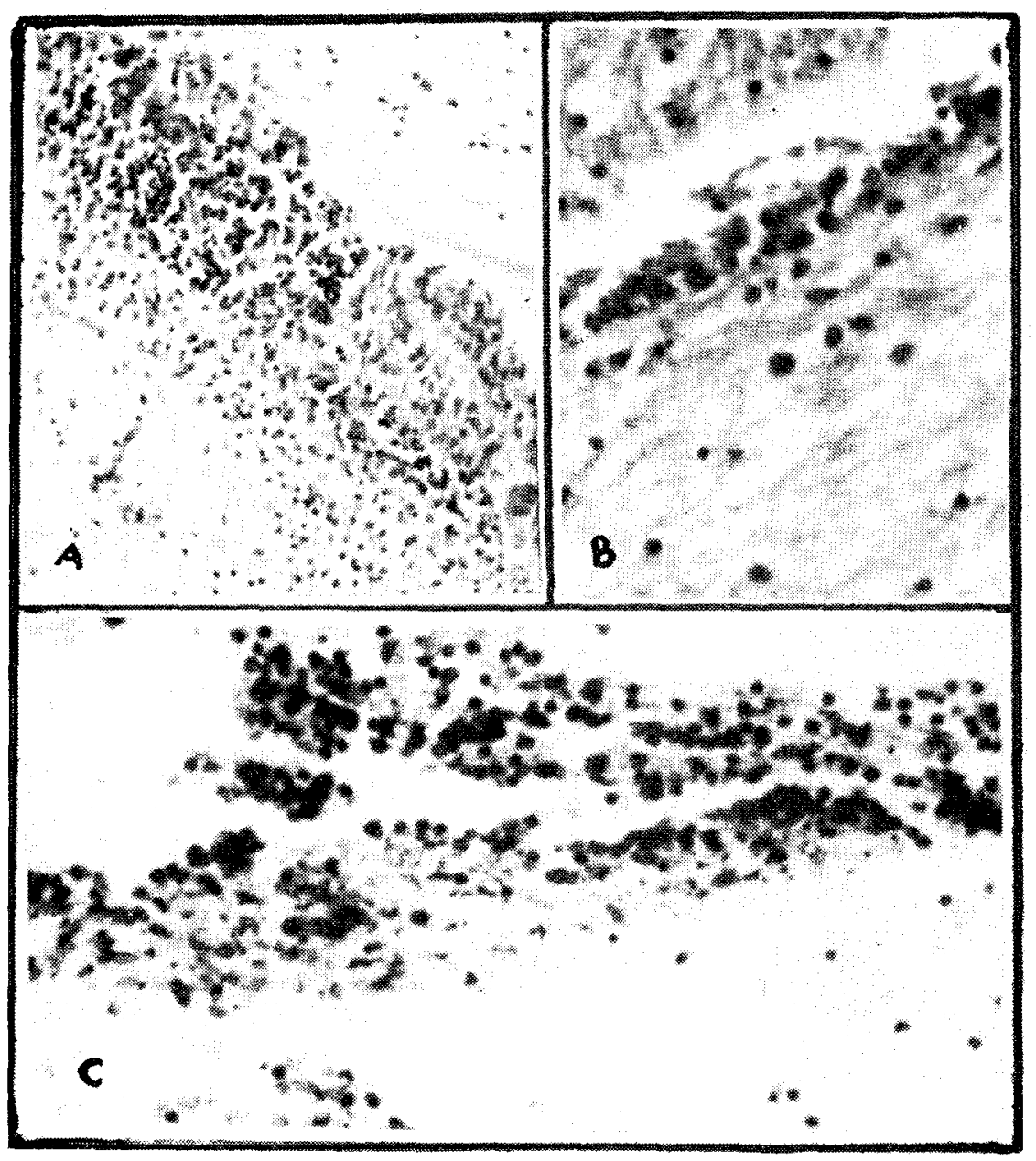

Fig. $5-$ COCAL!

Alterações celulares severas ao nivel do plexo coroide do ventriculo laterai (A), ependima do ventriculo lateral (B). Em (C) detalhe exibindo desarranjo e destruicão celular intensa. $H$ \& $E$ e Cresil-vloleta $100 \mathrm{X}$ e $200 \mathrm{X}$. 


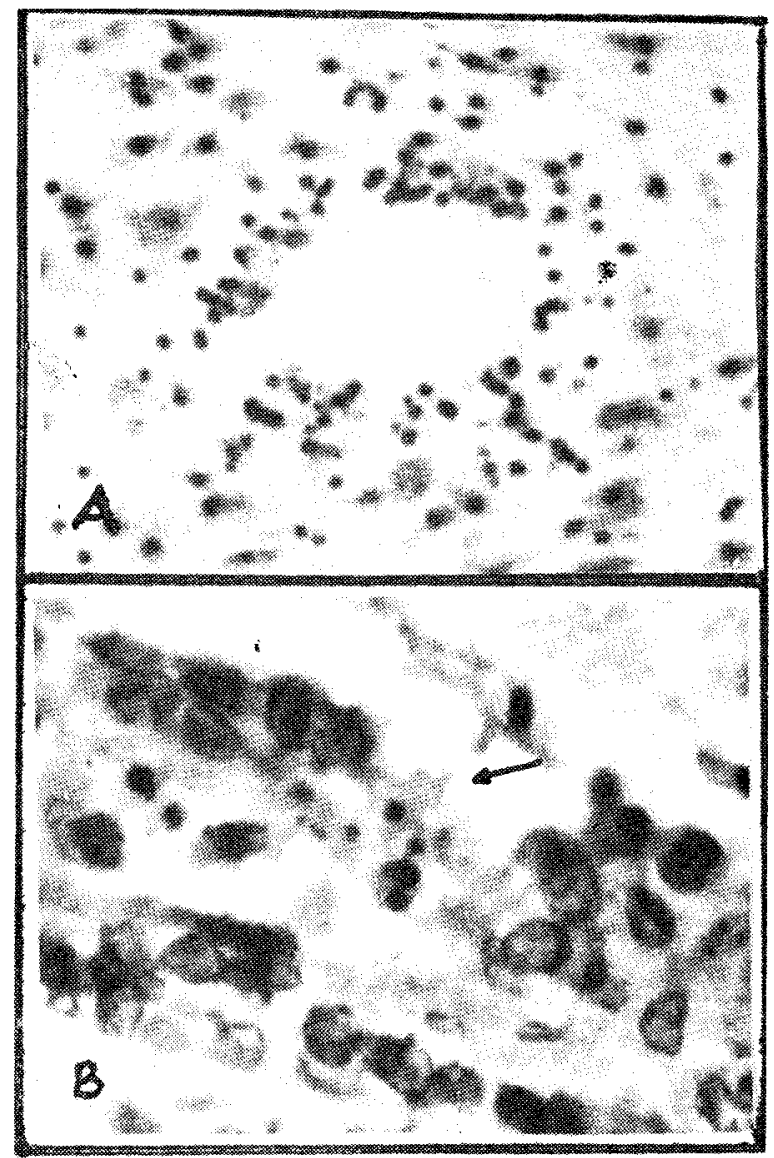

Fig. 6 - (COCAL)

Canal central medular com severa destruicäo do revestimento ependimário (A): em (B) ependimocitos exibindo intensa cariopicnose e cariorrexia, H \& E 120 X e $420 \mathrm{X}$ 


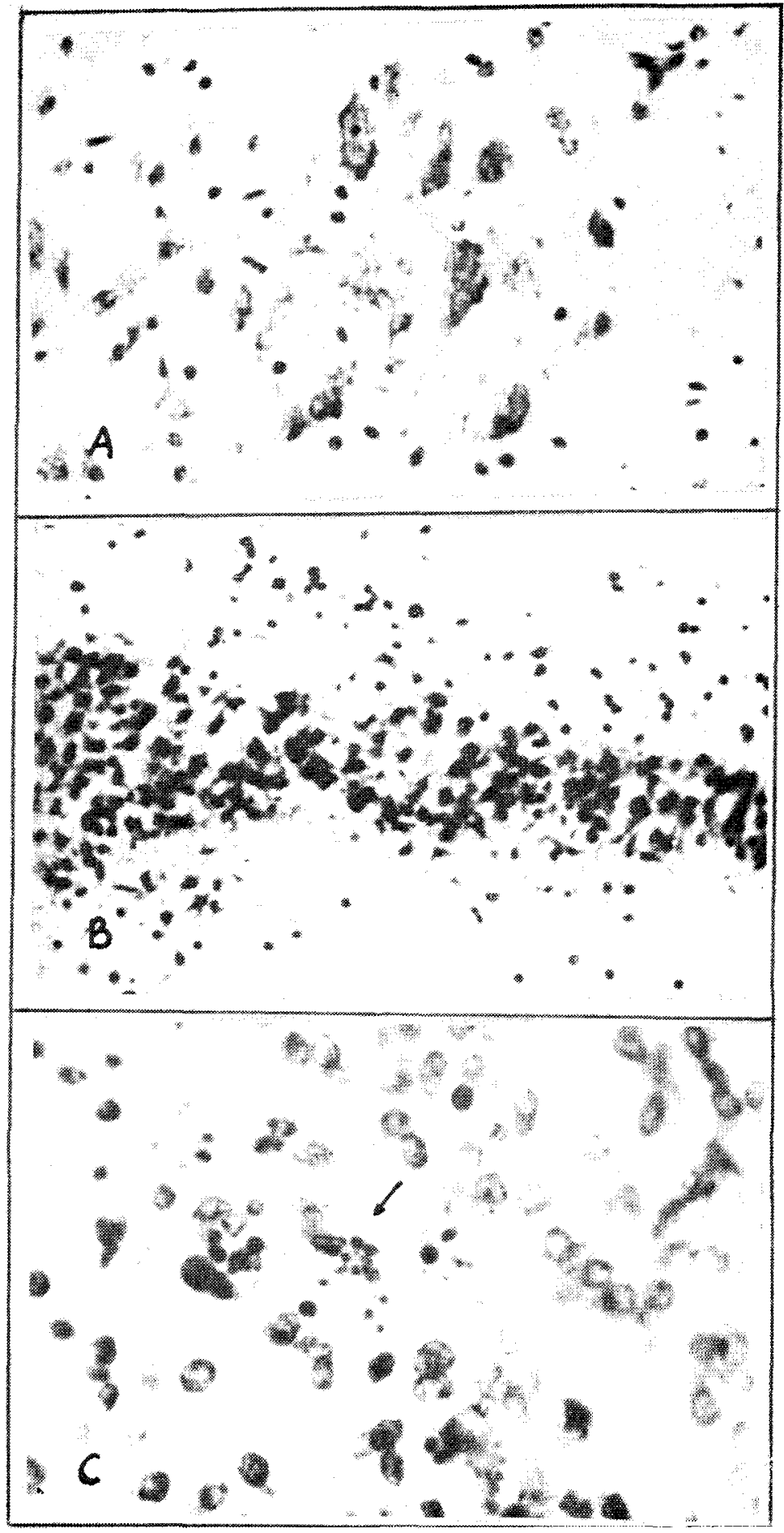

Fig. 7 , COCAL,

(A) ponta anterior da medula com alteracoes neuronais yraves: (B) Camada granular de hipocampo rarefeita por intensa destruiçāo neuronal: (C) Neurónios granulares exiblndo figuras de cariorrexia e cariopicnose (seta). Cresil-violeta. $360 \times, 120 \mathrm{X}$ e $460 \mathrm{X}$. 


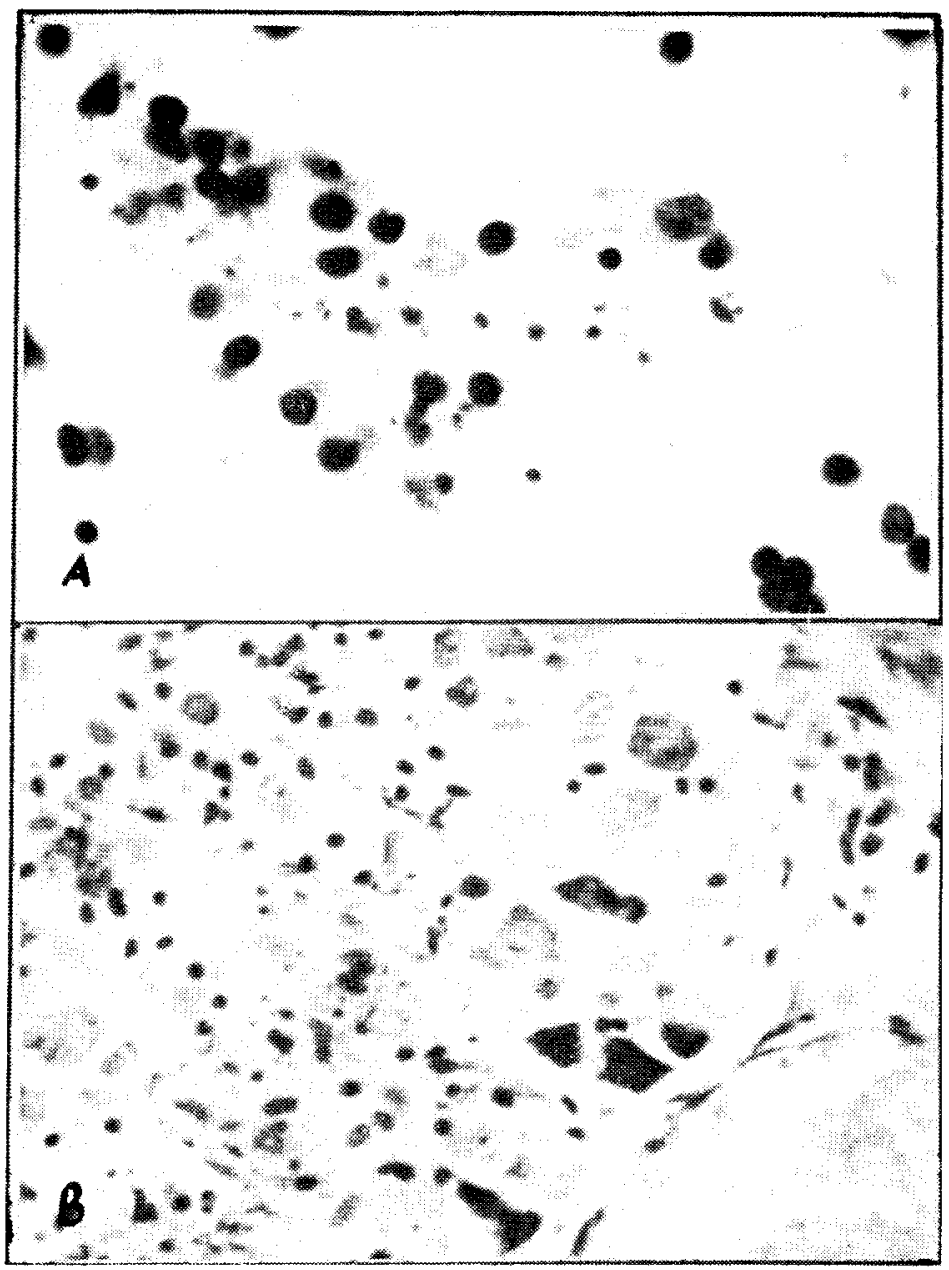

Fig. $8-$ COCAL

Em (A) lesōes severas en células g'liais observando-se intensa cariorrexia: em (B) variável espectro lesional neuronal com necrose parcial de ganorlo espinhal. Cresil-violeta. $240 \mathrm{x}$ 